\title{
Span Length Variance Effect on the Fatigue Life of FRP Bridge Deck
}

\author{
Ki-Tae Park, Young-Jun Yu, and Hyunseop Shin \\ Structural Engineering Research Division, KICT, 2311 Daehwa-Dong, Ilsanseo-Gu, Gyeonggi-Do, Goyang 411-712, Republic of Korea \\ Correspondence should be addressed to Ki-Tae Park; ktpark@kict.re.kr
}

Received 20 May 2013; Revised 21 August 2013; Accepted 2 September 2013

Academic Editor: Pavel Lejcek

Copyright (C) $2013 \mathrm{Ki}$-Tae Park et al. This is an open access article distributed under the Creative Commons Attribution License, which permits unrestricted use, distribution, and reproduction in any medium, provided the original work is properly cited.

\begin{abstract}
Fiber reinforced composite materials have the merits of light weight and durability for bridge deck and are estimated to be superior in economy to conventional deck materials considering the life-cycle cost of bridge. In this study, fatigue tests were conducted for the span lengths of $2.0 \mathrm{~m}$ and $2.5 \mathrm{~m}$ in order to investigate the change trend of fatigue characteristics of composite material deck according to the change in the span length. The result showed that the fatigue life rapidly reduces to about $25 \%$ when the span increases by $25 \%$. However, considering that the fatigue performance safety margin was approximately 1.6 times more than the design axle load of the DB-24 design truck load in Korea, even at the span of $2.5 \mathrm{~m}$, it is judged that the FRP decks being considered can be effectively used at a span length of $2.5 \mathrm{~m}$.
\end{abstract}

\section{Introduction}

Fiber reinforced composite materials have the merits of light weight, higher values of strength-weight and stiffness-weight ratios, and durability for bridge deck and are estimated to be superior in economy to conventional deck materials when considering the life-cycle cost of a bridge. Accordingly, studies on FRP decks with diverse shapes are actively conducted together with the studies on the performance verification by test procedure. However, studies on the fatigue performance and the change trend of the fatigue characteristics according to the change of span length, which is required for the studies on the longer-span FRP decks, have not been conducted.

Some of the cases related to the fatigue performance verification conducted for the FRP deck itself are described briefly below. Moon II [1] has conducted 3 types (connection details fatigue test, flexure fatigue test, and through-thethickness fatigue test) of fatigue tests with the deck modules constructed by the Ohio Department of Transportation, USA, and conducted verification and improvement for the design assumptions on the basis of the test results. Keller et al. [2] have suggested joint systems using resin by the method of connecting the FRP deck developed by the advanced structural systems for tomorrow's infrastructure (ASSET) in
Europe and by martin marietta composites (MMC) in the United States. The test results showed that no joint failures occurred when 10 million cycles were loaded on the two FRP decks. In addition, the available verification results include the fatigue performance tests conducted with the FRP deck materials such as Superdeck [3] and Duraspan [4] developed by American FRP materials related companies. Therefore, in this study, fatigue tests were carried out with the FRP decks developed by the Korea Institute of Construction Technology (KICT) for the span lengths of $2.0 \mathrm{~m}$ and $2.5 \mathrm{~m}$, in order to investigate the correlation between the span length and fatigue performance.

\section{Test Method}

2.1. Shape of the Test Specimens. The test specimen was the FRP deck developed by the KICT [5] through an optimization process. Figure 1 shows the section of the FRP deck module, and Figure 2 shows the module's pattern design result. Table 1 lists the physical properties of the FRP deck material by tests, and Table 2 lists the test specimens classified by the methods and fatigue test results. The values in the parenthesis in Table 2 are the ratio of the respective load range to the axle 


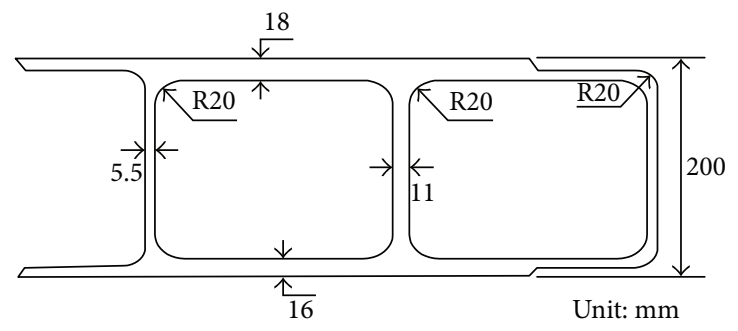

FIGURE 1: Shape of FRP bridge deck.

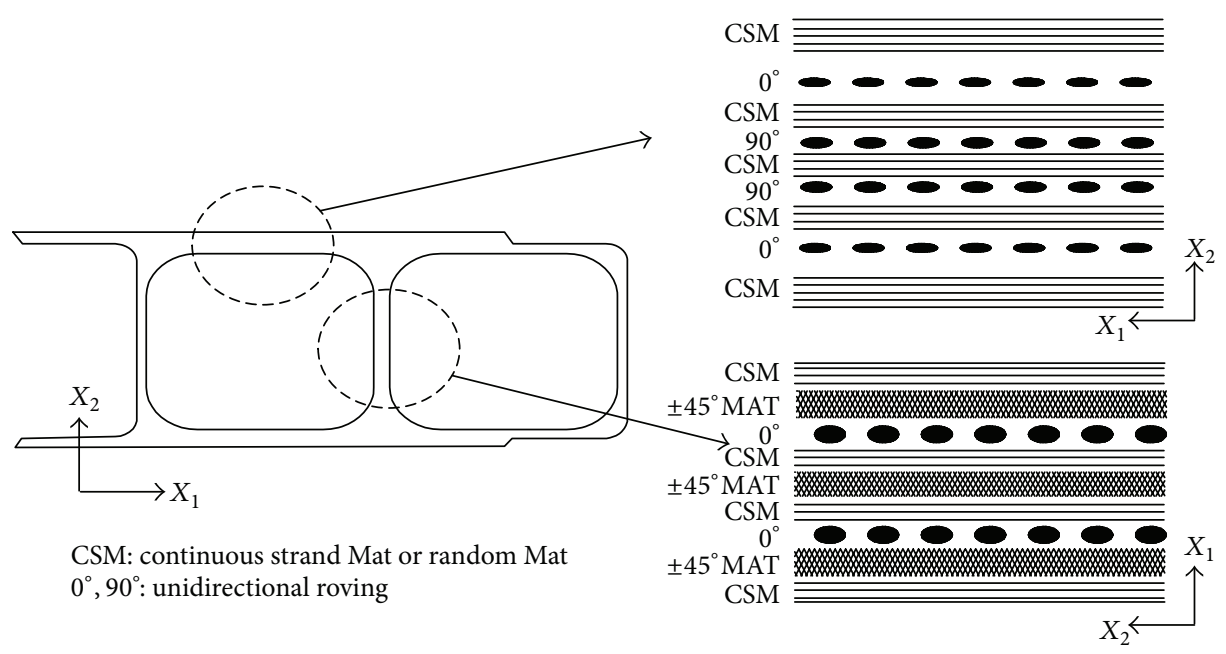

Figure 2: Pattern design of flange and web.

TABLE 1: Material properties of FRP (unit: MPa).

\begin{tabular}{|c|c|c|c|c|c|c|}
\hline \multirow{2}{*}{ Description } & \multicolumn{2}{|c|}{ Upper flange } & \multicolumn{2}{|c|}{ Web } & \multicolumn{2}{|c|}{ Lower flange } \\
\hline & Fiber direction & Vertical to fiber & Fiber direction & Vertical to fiber & Fiber direction & Vertical to fiber \\
\hline Elastic modulus & $28,300.0$ & $18,700.0$ & $31,100.0$ & $15,000.0$ & $27,800.0$ & $12,900.0$ \\
\hline Tensile strength & 309.0 & 54.7 & 497.3 & 51.2 & 341.3 & 72.4 \\
\hline Compressive strength & 326.1 & 175.7 & 512.0 & 164.7 & 459.0 & 168.0 \\
\hline Shear strength & $51.6^{1}$ & $40.3^{2}$ & $94.6^{1}$ & $29.0^{2}$ & $56.5^{1}$ & $28.1^{2}$ \\
\hline
\end{tabular}

${ }^{1}$ Inplane shear strength, ${ }^{2}$ interlaminar shear strength.

TABLE 2: Test specimen of the fatigue test.

\begin{tabular}{|c|c|c|c|c|c|}
\hline Span length $(\mathrm{m})$ & Minimum load $(\mathrm{kN})$ & Maximum load $(\mathrm{kN})$ & Load range $(\mathrm{kN})$ & Specimen number & Number of cycles \\
\hline \multirow{3}{*}{2.5} & 26.5 & 291.5 & $265(280 \%)$ & 1 & 550,000 \\
\hline & 18.7 & 205.7 & $187(190 \%)$ & 1 & 2.0 million \\
\hline & 15.0 & 165.0 & $150(160 \%)$ & 1 & Above 2.0 million \\
\hline \multirow{5}{*}{2.0} & 40.0 & 440.0 & $400(420 \%)$ & 1 & 50,000 \\
\hline & 35.0 & 385.0 & $350(360 \%)$ & 1 & 170,000 \\
\hline & 27.0 & 297.0 & $270(280 \%)$ & 1 & 500,000 \\
\hline & 24.0 & 264.0 & $240(250 \%)$ & 1 & 2.0 million \\
\hline & 12.5 & 137.5 & $125(130 \%)$ & 1 & Above 2.0 million \\
\hline
\end{tabular}




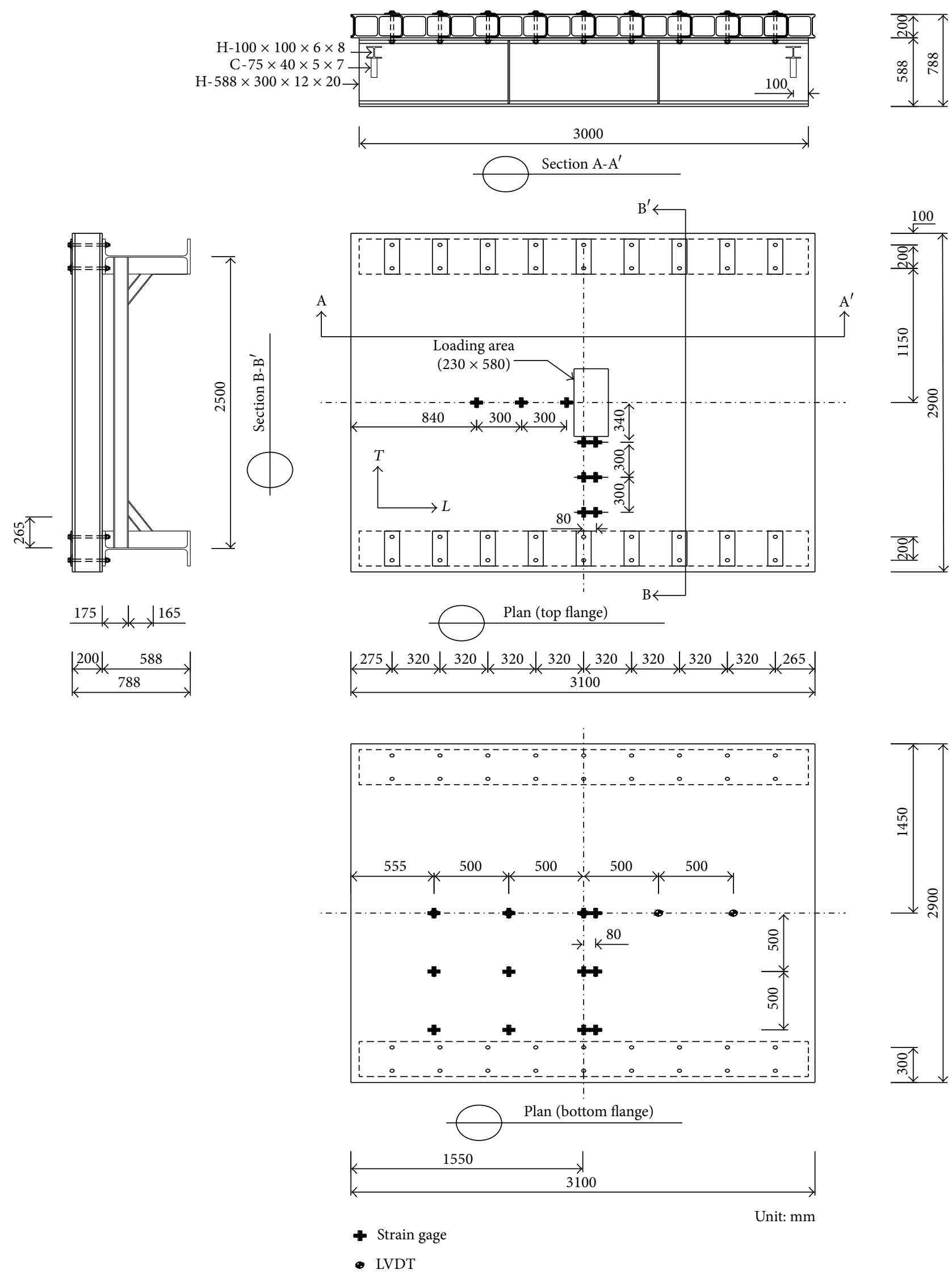

FIGURE 3: Dimensions of FRP deck and gauge position for fatigue test. 


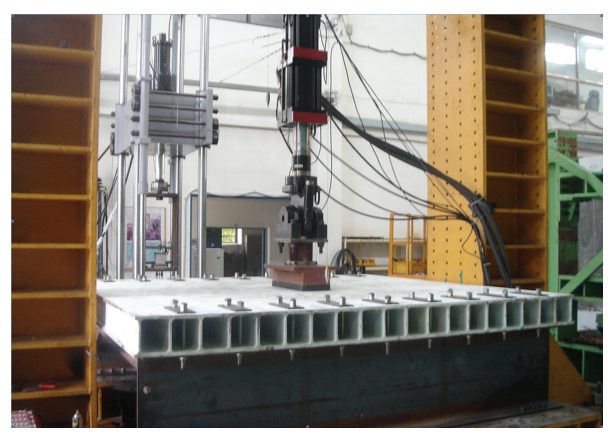

FIGURE 4: Fatigue testing with FRP deck.

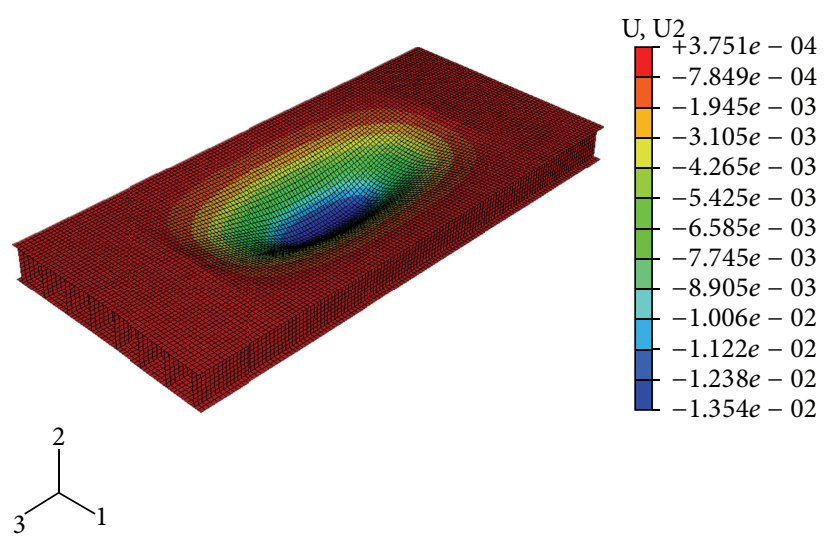

FIGURE 5: FRP deck displacement distribution.

load of $96 \mathrm{kN}$ of the DB-24 design truck load in Korea. And in this study, criteria of cycle load are determined as 2 million cycles by Korea Design Specification [6].

\subsection{Fatigue Test Method. The basic fatigue test configuration} for the span length of $2.5 \mathrm{~m}$ is shown in Figure 3. The fixing end which joins the girder was attached with bolts at $32 \mathrm{~cm}$ intervals. The steel girders have higher stiffness to prevent failure. The loading plate was set up to $23 \mathrm{~cm} \times 58 \mathrm{~cm}$ (crossways $\times$ vertical to crossways) simulating the axle load of vehicle. Static loading tests were conducted with the loading cycles of 1, 1000, 10,000, 50,000, 100,000, 500,000, 1,000,000, $1,500,000$, and 2,000,000, and the displacement and strain were measured at the position shown in the figure. The same tests were carried out by the same methods with the span length of $2.0 \mathrm{~m}$. Figure 4 shows the fatigue test setup.

Fracture static tests were conducted on the FRP deck specimens at each span length $(2.0 \mathrm{~m}, 2.5 \mathrm{~m})$ to acquire the basic data and set up the range for the fatigue loads. The basic configuration of the fracture test is the same as in Figure 3. The results of the fracture test and the structural analysis using the ABAQUS, a commercial finite element analysis program, can be shown in Table 3. In ABAQUS analysis, the bolt connection of FRP deck and steel girder was simply simulated using the coupling constraints for the FRP Deck bottom flange node and steel girder top flange node on the bolt connection positions as proposed by Park et al. [7], and linear elastic ranges are considered as analysis boundary. And also the S4R element, which is known to be as good to FRP bridge deck modeling for analysis is considered in this analysis. Failure load of analysis results is lower than that of test results, and this means that analytical results can be applied safely to the FRP deck application to bridge structure. Figures 5 and 6 show the displacement by finite element analysis and failure index distributions obtained by the TsaiHill failure analysis for the specimens span length of $2.0 \mathrm{~m}$.

\section{Test Result Analysis}

3.1. For $2.0 \mathrm{~m}$ Span Length. Figure 7 shows the stress distributions on the upper and lower surfaces of deck where the stresses were larger in the fatigue tests conducted in the applied load ranges.

For $125 \mathrm{kN}$ which is the DB24 design axle load $96 \mathrm{kN}$ multiplied by the impact factor 1.3 and $240 \mathrm{kN}$, stable behavior was observed up to the 2 million cycles which is the criteria of fatigue design [6]. In the load range of $270 \mathrm{kN}$ or more, displacement increased according to the number of cycle loading, and brittle fracture behavior of the test specimen was observed at the fatigue yield point [6].

Figure 8 shows the residual stresses after the load was removed, according to the load ranges. It can be seen that, for the load ranges which do not satisfy 2 million cycles, the residual stresses were larger than those under different 


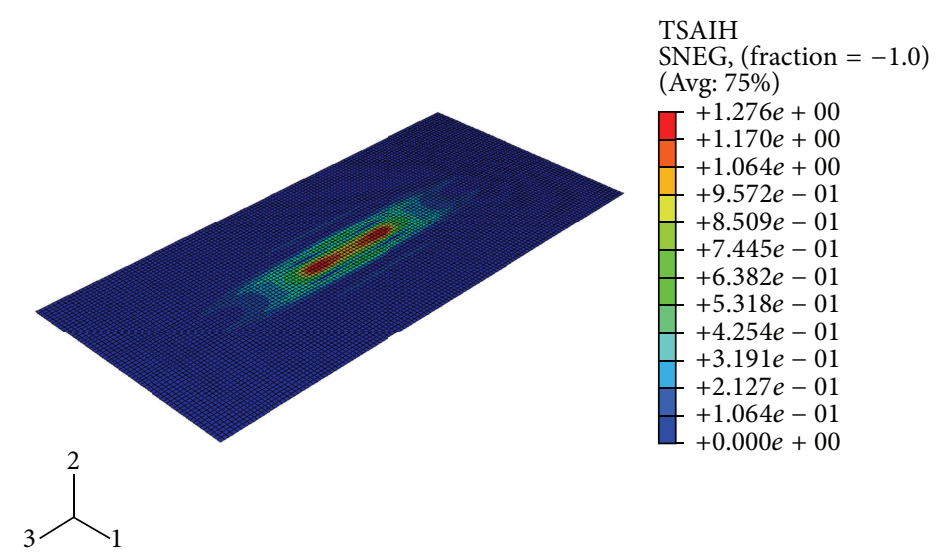

(a) Upper flange

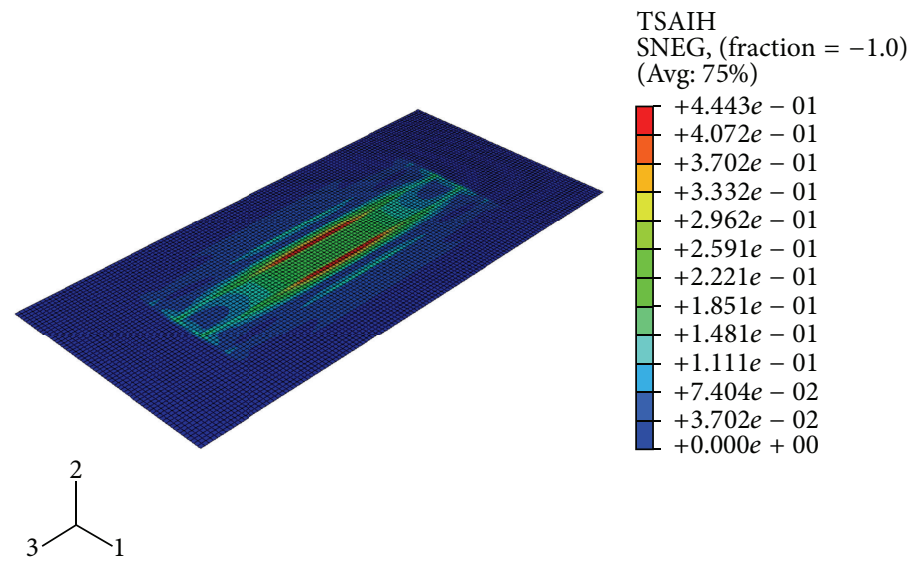

(b) Lower flange

FIGURE 6: FRP deck failure index distribution.

TABLE 3: Fracture tests and analysis results for $2.0 \mathrm{~m}$ and $2.5 \mathrm{~m}$ span lengths.

\begin{tabular}{lcccc}
\hline \multicolumn{2}{c}{ Classification } & Failure load $(\mathrm{kN})$ & Failure displacement $(\mathrm{mm})$ & Load/displacement $(\mathrm{kN} / \mathrm{mm})$ \\
\hline \multirow{3}{*}{ Span length $2.0 \mathrm{~m}$} & Experiment & 633 & 22.9 & 27.6 \\
& Analysis & 293 & 9.5 & 30.8 \\
& Experiment/analysis & 2.16 & 2.41 & - \\
Span length $2.5 \mathrm{~m}$ & Experiment & 417 & 27.2 & 15.3 \\
& Analysis & 236 & 10.0 & 23.6 \\
& Experiment/analysis & 1.77 & 2.72 & - \\
\hline
\end{tabular}

load conditions, and the increased residual stress indicates the probability of fatigue failure increase. And also, the trend of residual stress boundary may be larger as the load value is higher. And maximum and minimum residual stress are, respectively, in case of upper and lower flange- $270 \mathrm{kN}$.

3.2. For $2.5 \mathrm{~m}$ Span Length. Figure 9 shows the distributions of displacement and strain for the span length of $2.5 \mathrm{~m}$ by loading cycle, applied load range, and measurement position. The static load for each load cycle was set to $165 \mathrm{kN}$ which is the maximum load for the load range obtained by considering the impact factor of 1.3 and the safety factor of 1.3 to the $96 \mathrm{kN}$ which is the design axle load of DB24. The strain here refers to the value on the lower flange.

In the load range of $187 \mathrm{kN}$, multipling $96 \mathrm{kN}$ by impact factor 1.3 and safety factor 1.5, the fatigue design criteria of 2 million cycles or more were satisfied. Therefore, it was determined that the optimal load range meeting the 2 million cycles is between $187 \mathrm{kN}$ and $265 \mathrm{kN}$.

The relatively increasing trend of the stress, consisting of the multiple of the measured strain above and the modulus of elasticity, and the displacement by loading cycle number, that is, the residual stress and residual displacement by loading cycle number, are shown in Figure 10. 

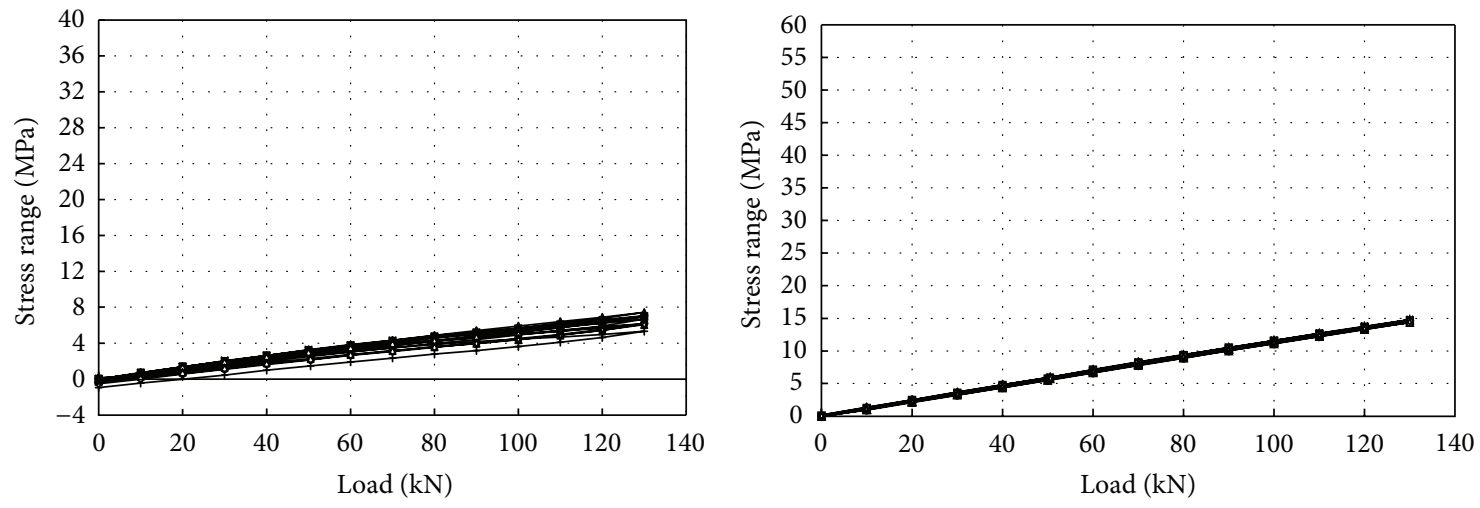

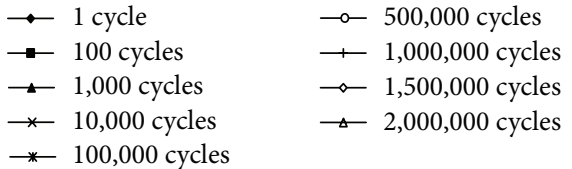

(a) Upper flange $(125 \mathrm{kN})$

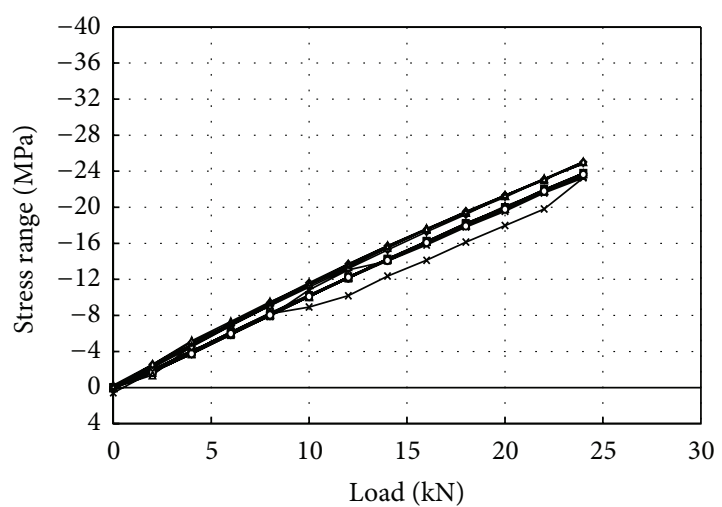

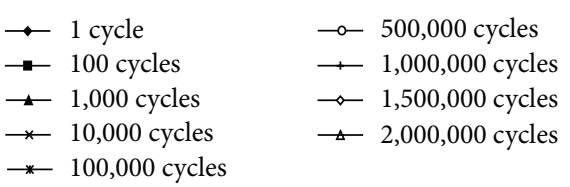

(c) Upper flange $(240 \mathrm{kN})$

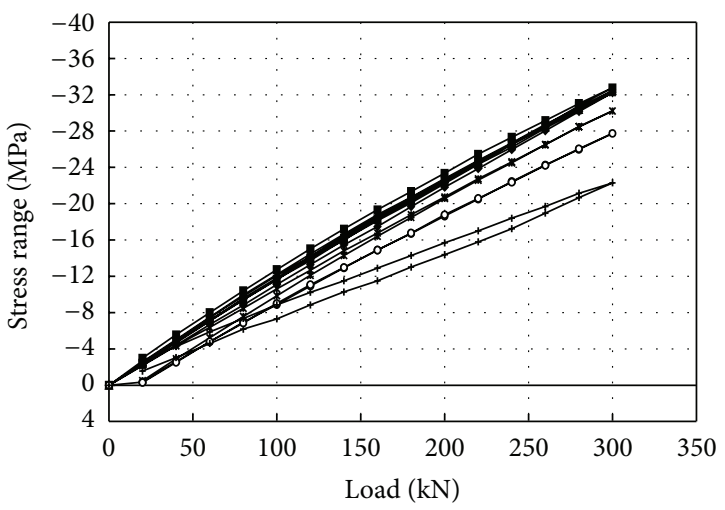

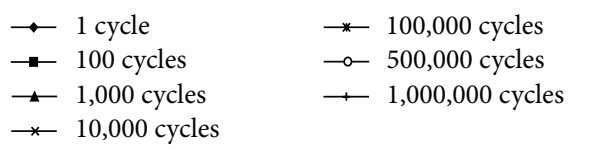

(e) Upper flange $(270 \mathrm{kN})$

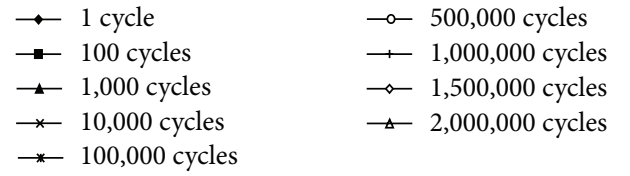

(b) Lower flange $(125 \mathrm{kN})$
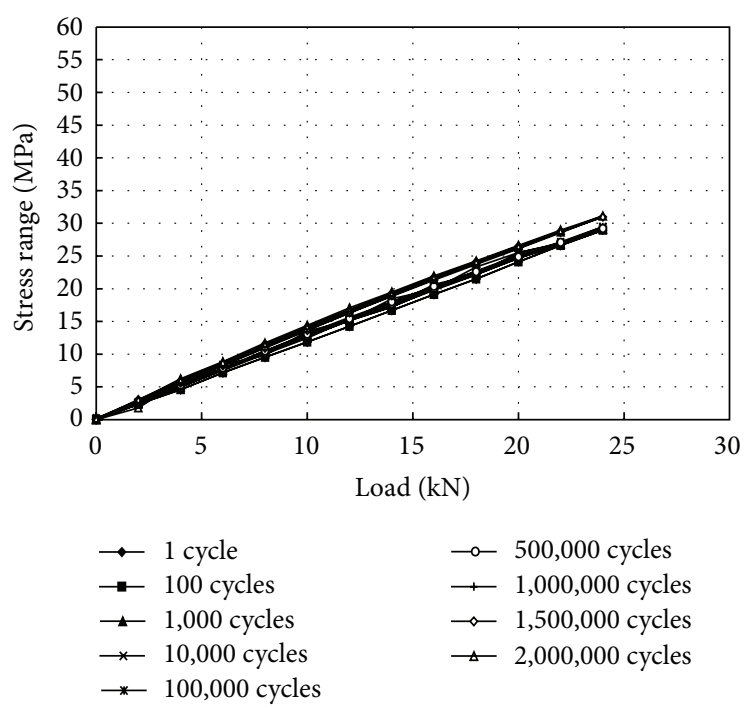

(d) Lower flange $(240 \mathrm{kN})$
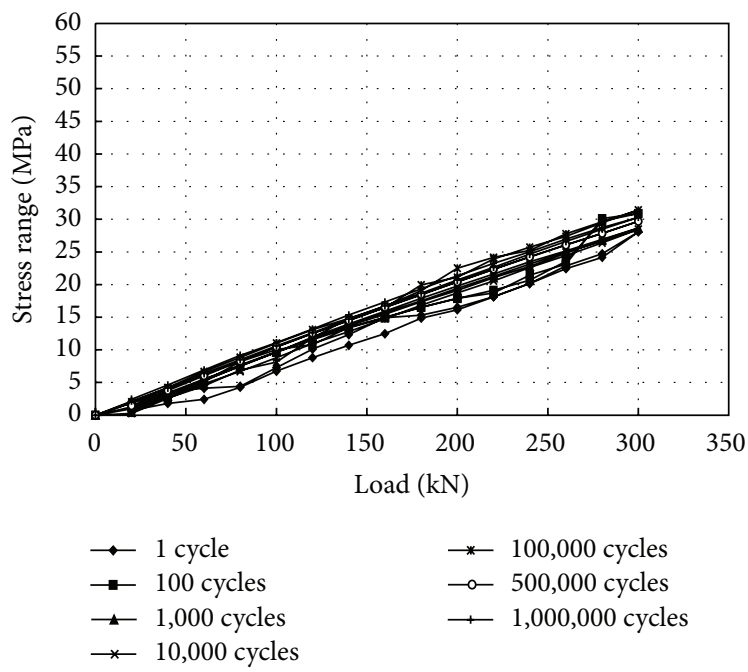

(f) Lower flange $(270 \mathrm{kN})$

FIGURE 7: Continued. 


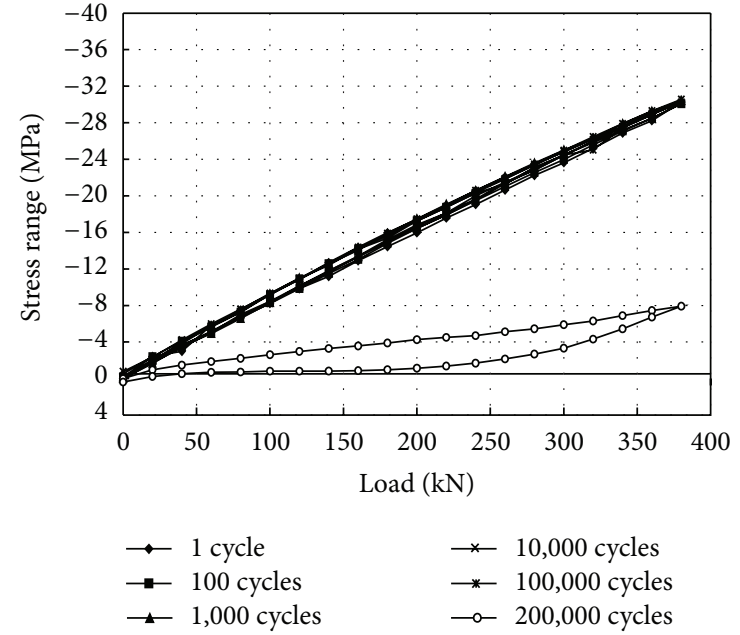

(g) Upper flange $(350 \mathrm{kN})$

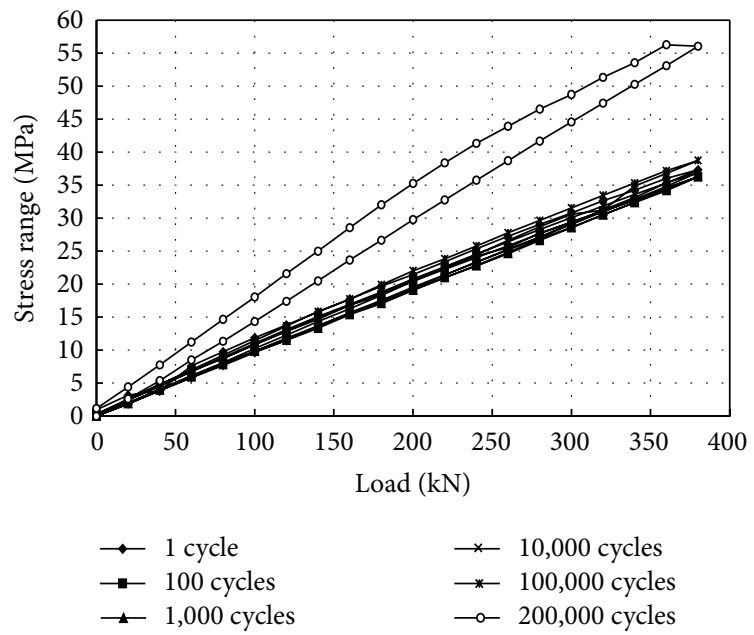

(h) Lower flange $(350 \mathrm{kN})$

FIGURE 7: Load Range-Stress Correlation at Span Length of $2.0 \mathrm{~m}$.

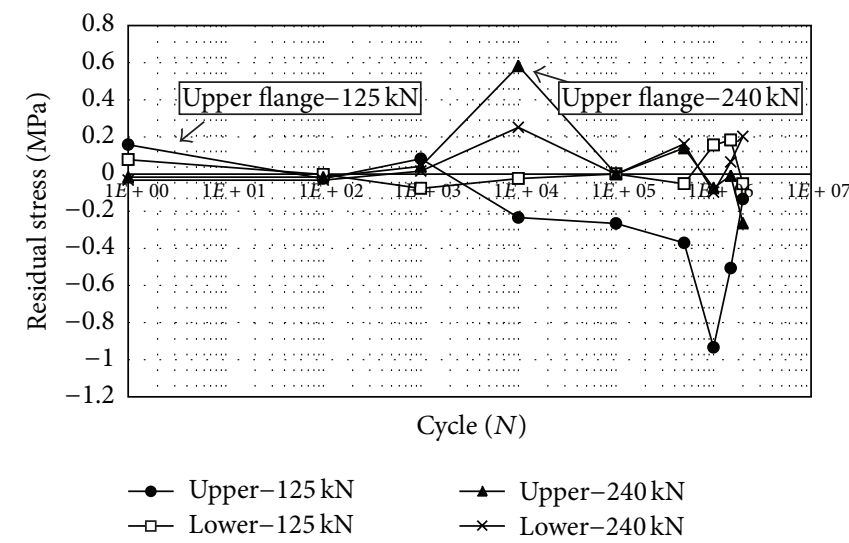

(a) Residual stress $(125 \mathrm{kN}, 240 \mathrm{kN})$

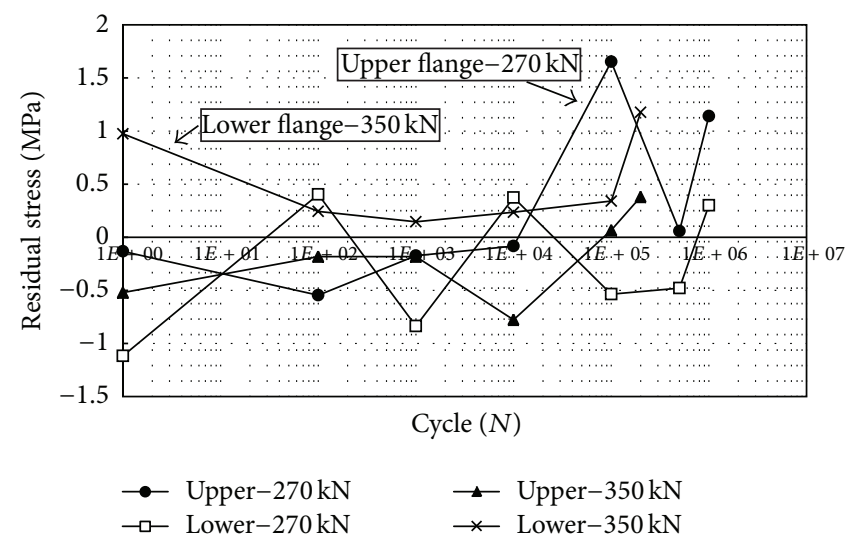

(b) Residual stress $(270 \mathrm{kN}, 350 \mathrm{kN})$

FIgURE 8: Load range-residual stress correlation at span length of $2.0 \mathrm{~m}$.

\section{Comparative Analysis of the Test Results}

For the span lengths of $2.0 \mathrm{~m}$ and $2.5 \mathrm{~m}$, the relation between the number of loading cycles and the maximum load was compared and presented in Figure 11. The data for the load ranges exceeding 2 million cycles per span length in the above tests was neglected in the graph.

Calculating the number of loading cycles which correspond to the design criteria of 2-million-cycle load [6] using the trend line formulas shown in Figure 11, with the $125 \mathrm{kN}$ which is the multiple of the DB24 design axle load and the impact factor of 1.3 as the criteria, it was estimated that the failures occur at about 25 million cycles in $2.0 \mathrm{~m}$ span length and at 6.4 million cycles in $2.5 \mathrm{~m}$ span length, from the test results. This means that the fatigue life was reduced to about $25 \%$ when the span length was increased by $25 \%$, and the loads that satisfy the 2-million-cycle fatigue design criteria were estimated to be about $250 \mathrm{kN}$ in $2.0 \mathrm{~m}$ span and about $205 \mathrm{kN}$ in $2.5 \mathrm{~m}$ span.
Figure 12 shows the correlation between the axle loads that meet the 2-million-cycle criteria, which are the fatigue design criteria and the span length, under the presumption that the relation is linear, log, or exponential functions. As shown in the figure, it can be estimated that the fatigue performance of FRP deck can be satisfied for the span length of $3.0 \mathrm{~m}$.

The main failure modes by fatigue test were local deformation on the connection part of loaded surface of upper flange, fatigue crack in the upper flange, fiber fractures in the upper flange, and web buckling failure.

\section{Conclusion}

In this study, fatigue tests were conducted to investigate the fatigue characteristics trend of the FRP deck developed by KICT according the change of span length. The results are summarized below. 

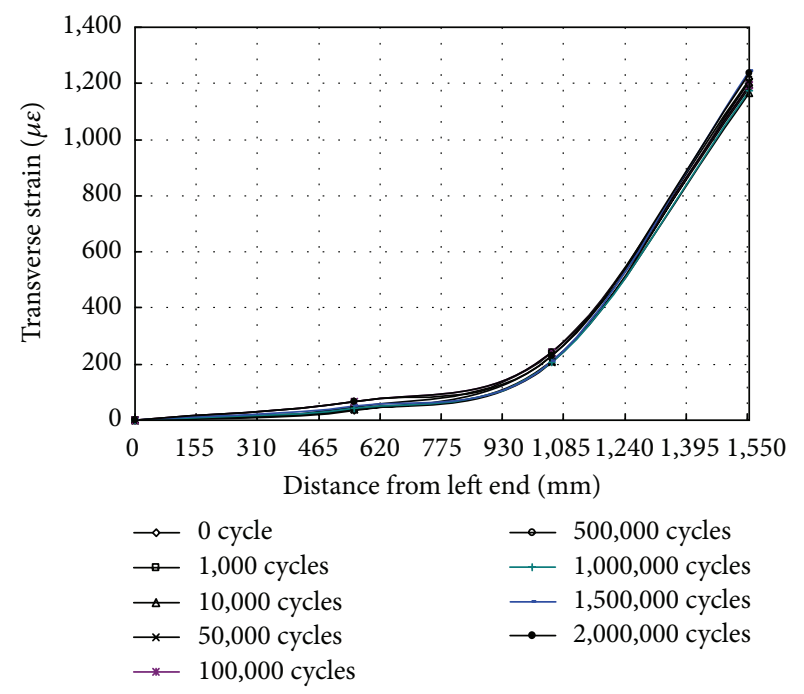

(a) Measured strain $(150 \mathrm{kN})$

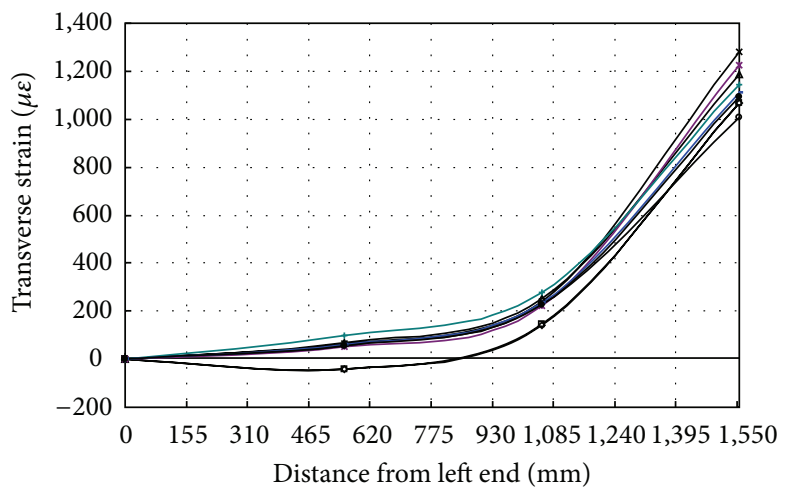

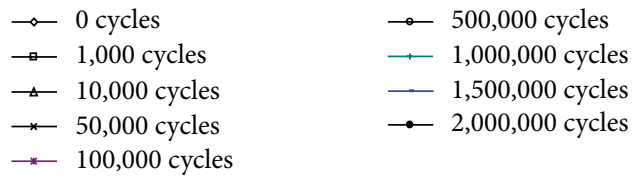

(c) Measured strain $(187 \mathrm{kN})$

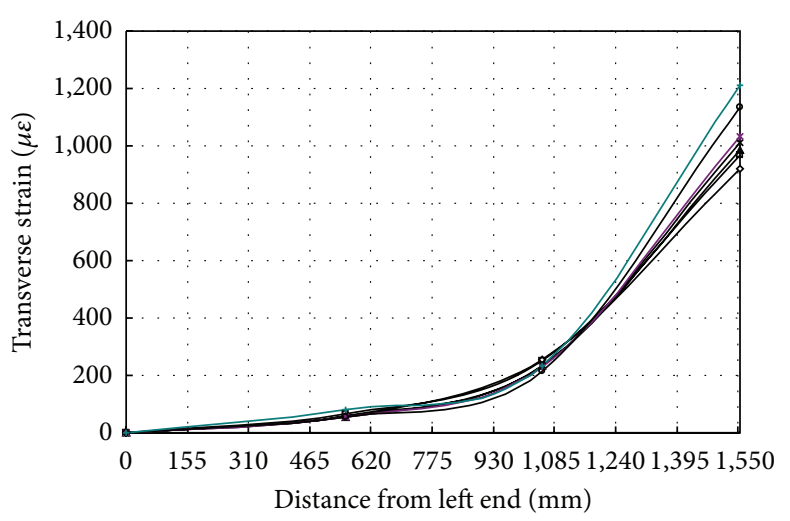

$$
\begin{aligned}
& \multimap 0 \text { cycles } \\
& \square \quad 1,000 \text { cycles } \\
& \varangle \quad 10,000 \text { cycles } \\
& \rightarrow \quad 50,000 \text { cycles }
\end{aligned}
$$

(e) Measured strain $(268 \mathrm{kN})$
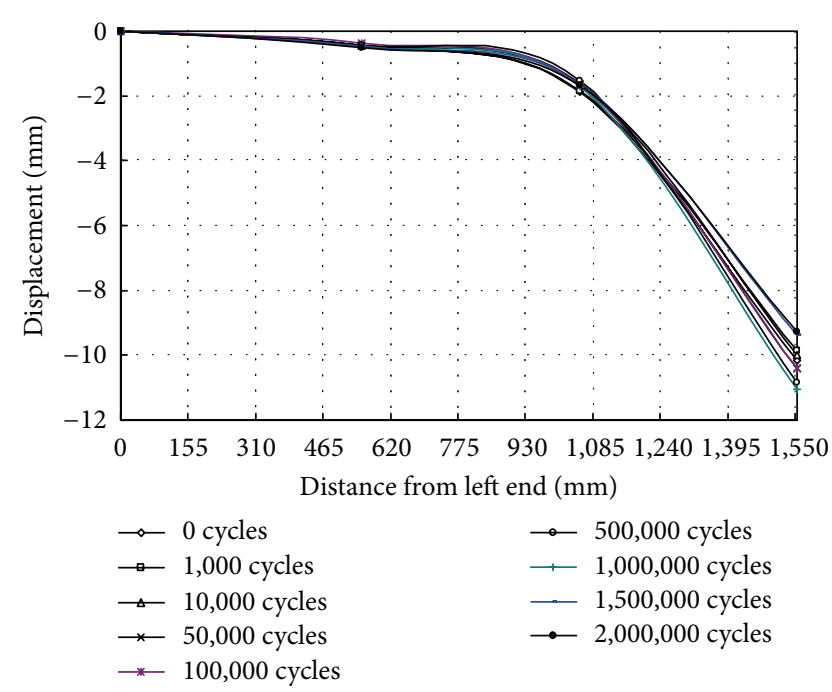

(b) Measured displacement $(150 \mathrm{kN})$

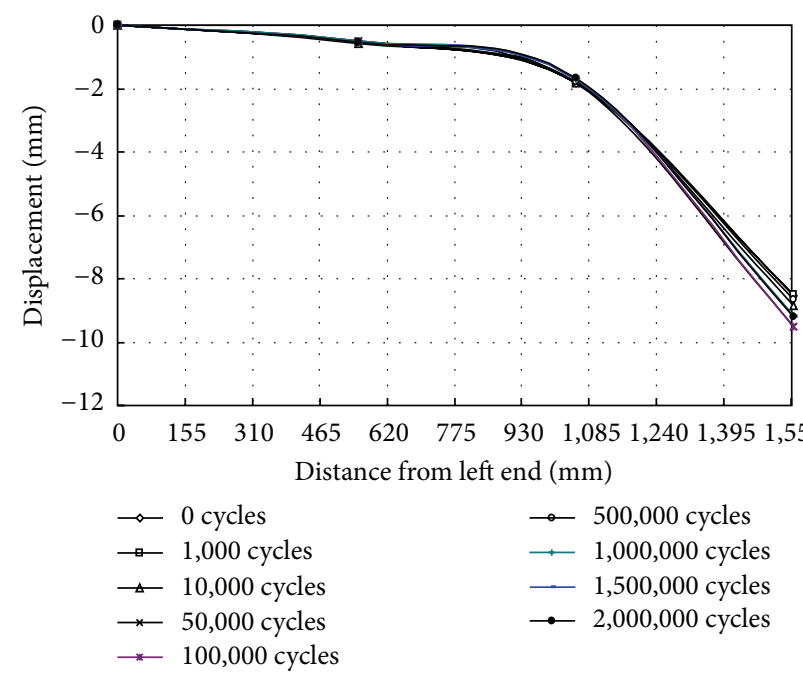

(d) Measured displacement $(187 \mathrm{kN})$

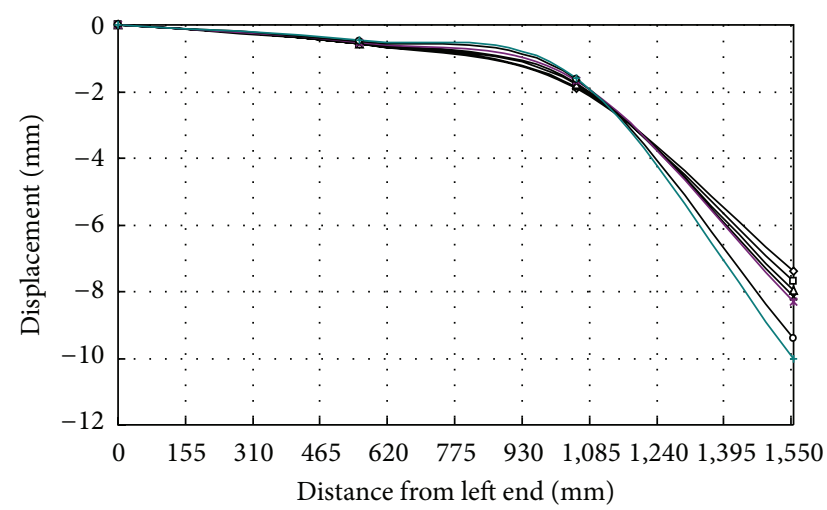

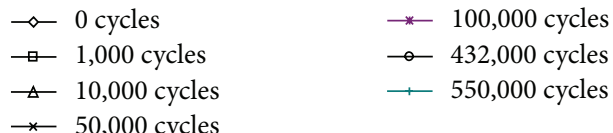

(f) Measured displacement $(268 \mathrm{kN})$

FiguRE 9: Load range-strain and displacement correlation at span length $2.5 \mathrm{~m}$. 


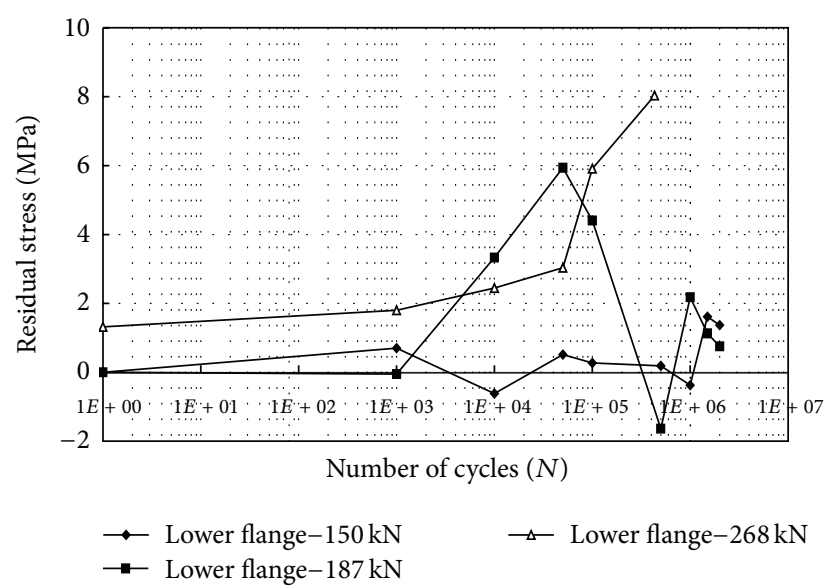

(a) Residual stress

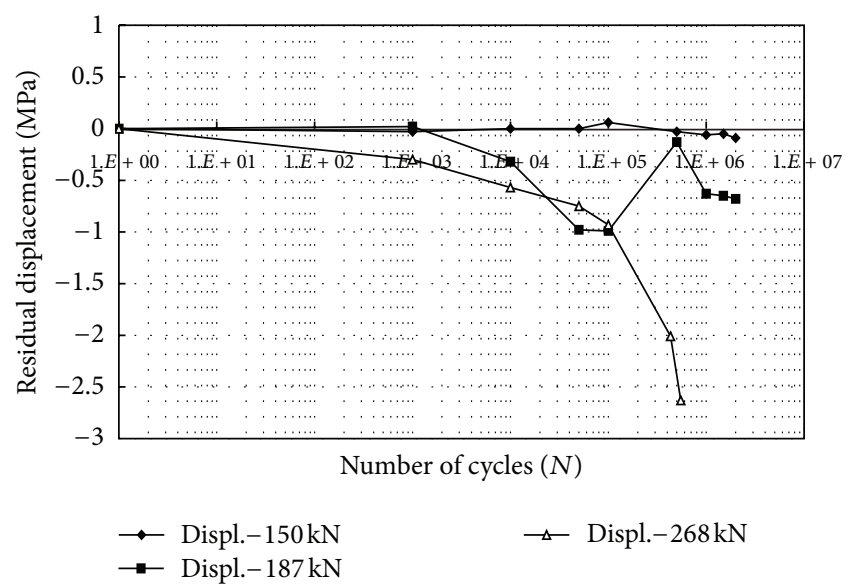

(b) Residual displacement

FIGURE 10: Correlation between cycle load-residual stress and displacement.

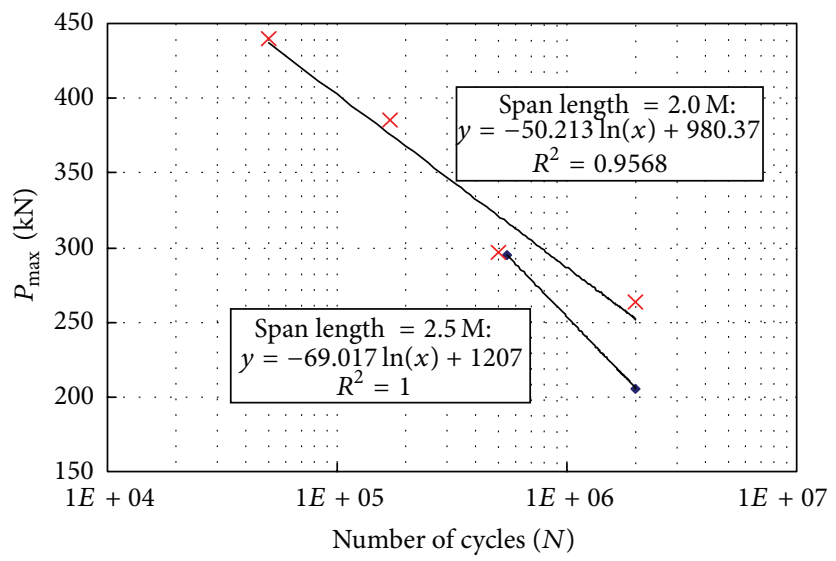

FIGURE 11: Correlation between the number of load cycles and maximum load.

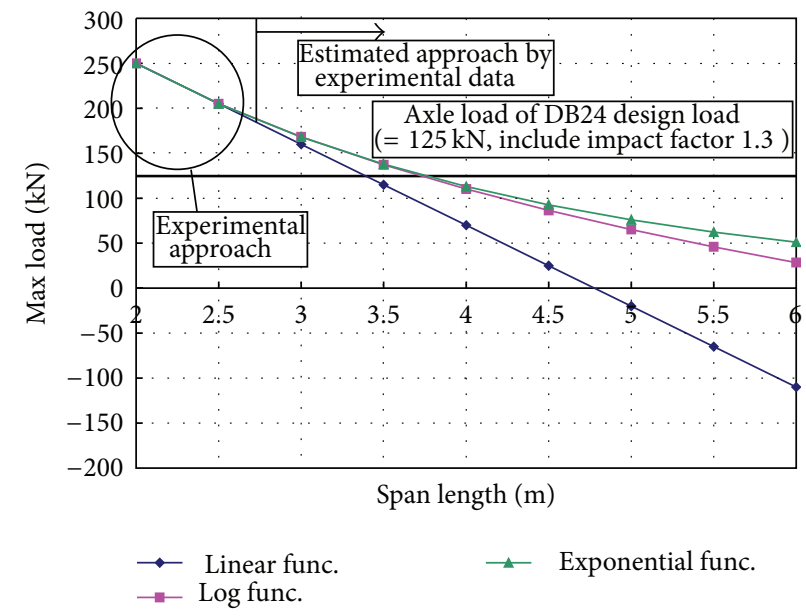

FIgURE 12: Estimation on the maximum load by span length. 
(1) In the fatigue test for the FRP deck in $2.0 \mathrm{~m}$ span length, stable behaviors were observed up to $240 \mathrm{kN}$ under the load cycle of 2 millions and the fatigue design criteria. In the load range of $350 \mathrm{kN}$ or higher, displacement increased according to increase the number of loading cycles, and brittle fracture behavior was observed at the fatigue yield point.

(2) In the fatigue test of FRP deck in $2.5 \mathrm{~m}$ span length, the 2 million load cycle was satisfied in the load range of $187 \mathrm{kN}$ which is the axle load $96 \mathrm{kN}$ the standard design truck axle load for DB24 multiplied by the impact factor 1.3 and safety factor 1.5. The optimal load range satisfying the 2-millionload-cycle criteria was within $187 \mathrm{kN}$ and $265 \mathrm{kN}$ range.

(3) The maximum loads meeting the 2-million-load-cycle criteria were estimated to be about $250 \mathrm{kN}$ in $2.0 \mathrm{~m}$ span and about $205 \mathrm{kN}$ in $2.5 \mathrm{~m}$ span. These are 2.0 times and 1.6 times of the $125 \mathrm{kN}$ which is the multiple of the axle load criteria of design truck load DB-24 and impact factor 1.3, respectively, showing that span length of $2.5 \mathrm{~m}$ satisfies the fatigue performance required for bridge deck.

(4) In this study, considering the dimensions of the specimen and time, tests were conducted on 8 decks to investigate the correlation between the maximum load and number of loading cycles. On the basis of the results of the fatigue tests conducted in the span lengths of $2.0 \mathrm{~m}$ and $2.5 \mathrm{~m}$, it was estimated that the span length of $3.0 \mathrm{~m}$ can meet the fatigue design criteria as well. However, as this result was obtained from the analytical approach on the basis of partial tests, drawing up reasonable $S-N$ diagram by conducting fatigue tests for diverse span lengths will be required for the maximization of the use of FRP decks.

\section{Acknowledgment}

This project was supported by the KICT's basic project named "Harbor Structure's Performance Improvement Technologies Using FRP Composites."

\section{References}

[1] F. L. Moon II, Large-Scale Experimental Validation of an AllComposite Bridge Deck and Deck Connections [Ph.D. thesis], University of Delaware, 2000.

[2] T. Keller, H. Gurter, and A. Zhou, Performance of Adhesively Bonded FRP Deck and Steel Bridge Girders, ACMBS-IV, Calgary, Canada, 2004.

[3] R. Lopez-Anido, H. V. S. GangaRao, V. Vedam, and N. Overby, "Design and evaluation of a modular FRP bridge deck," in Proceedings of the International Composite SPI-Composites Institute (Expo '97), Nashville, Tenn, USA, 1997.

[4] DARPA, Advanced Composites For Bridge Infrastructure Renewal-Phase II. Final Report, Defense Advanced Research Projects Agency, Department of Defense, 2000.

[5] Korea Institute of Construction Technology (KICT), "Development of GFRP bridge decks-year two (in Korean)," Report No. KICT 2003-059, Goyang, Korea, 2005.

[6] Minstry of Construction and Transportation (MOCT), Standards Specifications For Highway Bridges (in Korean), 2nd edition, 2005.
[7] K.-T. Park, S.-H. Kim, Y.-H. Lee, and Y.-K. Hwang, "Degree of composite action verification of bolted GFRP bridge deck-togirder connection system," Composite Structures, vol. 72, no. 3, pp. 393-400, 2006. 

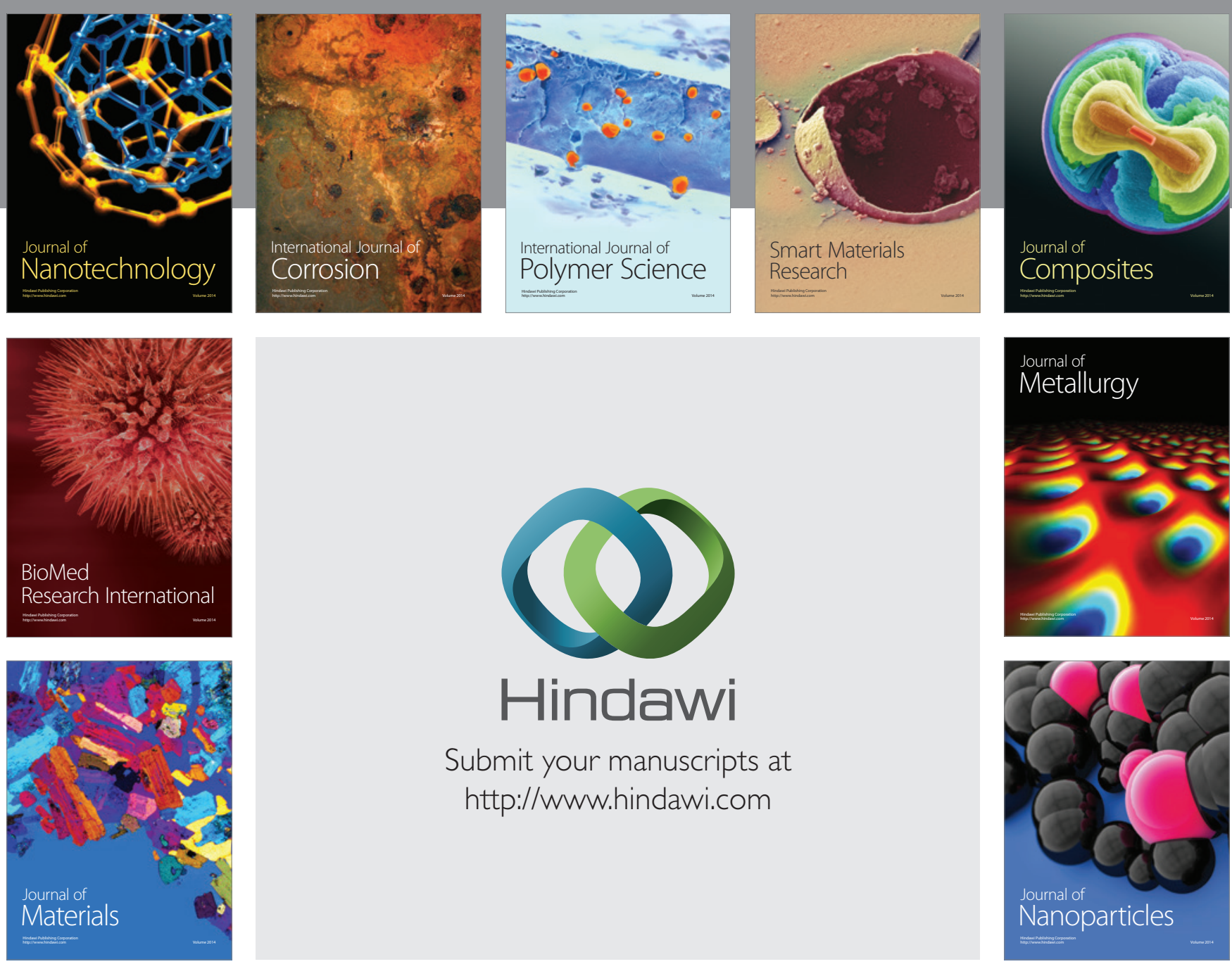

Submit your manuscripts at http://www.hindawi.com
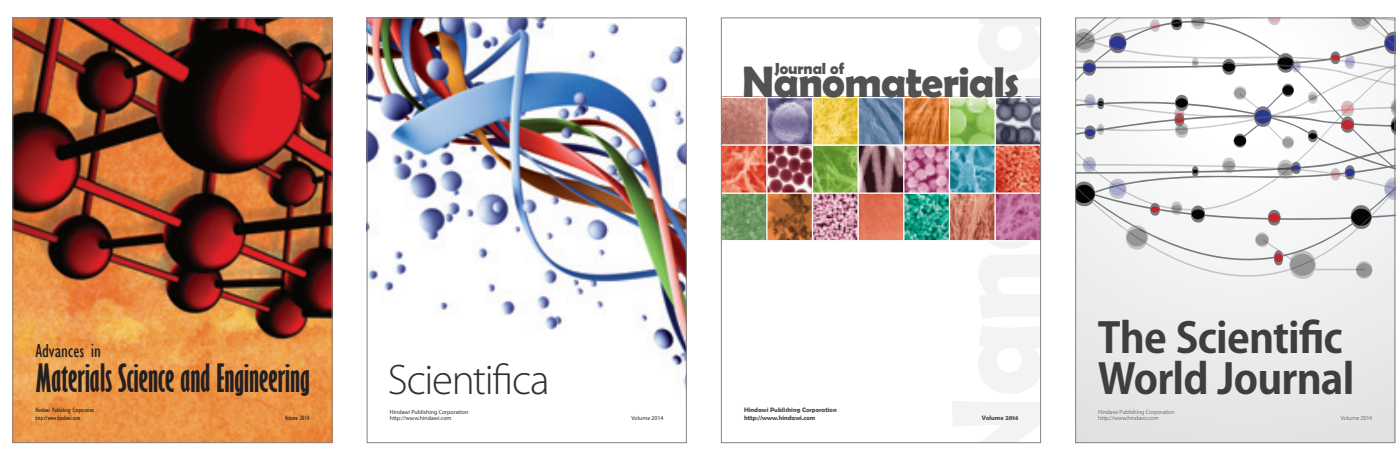

\section{The Scientific World Journal}
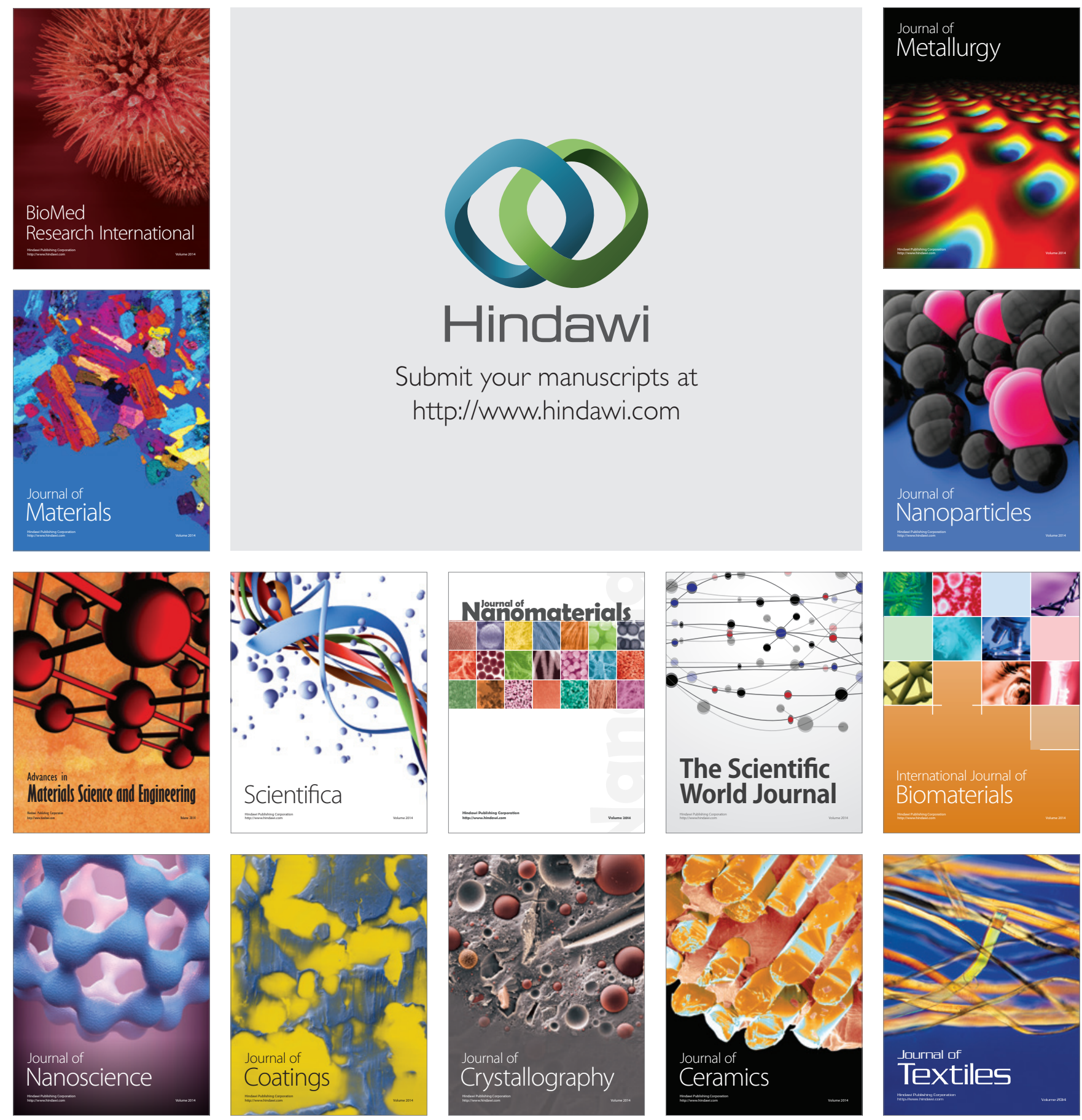